\title{
English Bar as a Venue to Boost Students' Speaking Self-Efficacy at the Tertiary Level
}

\author{
Mingxu Liu ${ }^{1}$ \\ ${ }^{1}$ School of Translation Studies, Jinan University, Zhuhai, China \\ Correspondence: Mingxu Liu, School of Translation Studies, Jinan University, Zhuhai, China. Tel: \\ 86-138-2308-4226. E-mail: jnuliu@126.com
}

Received: August 9, 2013 Accepted: September 25, 2013 Online Published: November 5, 2013

doi:10.5539/elt.v6n12p27 URL: http://dx.doi.org/10.5539/elt.v6n12p27

\begin{abstract}
Research in EFL and ESL has confirmed that self-efficacy affects language learners' choices of learning tasks, persistence, motivation and achievement. As a cognitive construct, self-efficacy can be strengthened by both outcomes of behaviors and input from the environment. This paper studies the effects of an English Bar, a self-access center for students to practice oral English, on Chinese college students' self-efficacy enhancement. The study's questionnaire and in-depth interviews reveal that students who often go to the Bar to speak in English demonstrate considerably higher levels of self-efficacy than their peers who seldom or never visit the Bar. Finally, the implications and limitations of the study are discussed.
\end{abstract}

Keywords: communicative competence, self-efficacy, aptitude, English Bar

\section{Introduction}

College English Teaching (CET) in China has been the target of pubic criticism for its intensive investment but low effectiveness. Even though students take College English as a required course for two years and a few elective ESP and EAP courses for another year, a large number of graduates leave the college campus speaking very poor English. This low effectiveness impedes their employment prospect and career development. In a study of college graduate's general English competence, Liu (2011) finds that over two-thirds of the graduates reported that their English listening and speaking skills could not meet the requirements for jobs in a globalized context. Though more students graduate with the National College English Test (CET-4) certificate, their practical language competence, especially oral communicative competence, does not improve accordingly (Cai, 2011).

Earlier studies attribute such incompetence to Chinese learners' use of strategies. Chinese English learners are often criticised as 'proverbial rote memorizers or recyclers' (Decket, 1993, p. 133), 'relentless rote learners' (Briggs, 1991, p. 27), or syllabus-dependent and passive (Flowerdew \& Miller, 1995). Others see the issue from a cultural perspective. Cortazzi and Jin (1996) suggest that 'Chinese culture of learning' encourages rote learning and constrains learners from being active. $\mathrm{Hu}(2002,2005)$ supports the view that Chinese English learners are constrained by a traditional learning culture where learners are not viewed as active users but passive receivers of knowledge passed on by teachers. However, individual and cultural characteristics may not be sufficient to explain the whole phenomenon. Some scholars such as Gao (2006) maintain that English learners in mainland China do not have enough opportunities to interact with proficient native English speakers beyond the classroom. Apart from individual, cultural and environmental limitations which might influence learners' use of strategies and learning outcomes, language education policy and associated pedagogical factors may be salient $(\mathrm{Hu}, 2003$; Jiang and Smith, 2008). Reading skills had been the focus of college English teaching and learning until 2007 when the Ministry of Education of China issued the English Course Requirements for Non-English Majors in which communicative skills, especially listening and speaking skills, were given priority in English teaching at the tertiary level.

The implementation of the new guideline throughout the country led to college English teaching reform including redesigning curriculum, compiling new textbooks based on the communicative approach, restructuring achievement evaluation to give more weight to formative evaluation. In addition, more Chinese English teachers have the opportunity to study in English-speaking countries as visiting scholars or as part of exchange programs. They come back with advanced oral English, a broader vision, and above all, the latest language acquisition 
theories and teaching methodologies. Pedagogic transformation not only affects English classrooms but also extracurricular activities that are thought to supplement the inadequate in-put and out-put practice in English class. Besides the traditional English corners, new English clubs, self-access centers and English learning centers have been set up on university campuses to facilitate students' learning, especially speaking skills beyond classrooms.

Among the few studies on 'English Corners', some (Li, 2004) discussed their functions in general and the effects on the participants' oral English. Gao (2006b) studied English corners in mainland China from socio-cultural and humanistic learning perspectives and found that the evolution and self-identity construction of individual learners in the venues potentially help sustain their autonomous language learning efforts. Despite the findings that indicate the potential benefits of English corners on the participants, these studies are of qualitative nature and thus lack solid statistical verification. This study investigates the effects of a campus English Bar on college students' speaking self-efficacy, which in this context means students' perceived capability to conduct effective verbal communications with native and non-native speakers of English.

\section{Self-Efficacy and Second/Foreign Language Learning}

When it comes to the outcomes in learning a foreign language, individuals differ dramatically and the differences encompass a wide scope of causes including learners' factors, such as personality traits, learning strategies, learners' aptitudes, motivation, as well as environmental factors such as means of instruction, media use, the Internet access, course books, the instructors, etc. In the past decades, there has been a growing research interest in self-efficacy beliefs in the context of foreign/second language learning (Raoofi, Tan, and Chen, 2012). Self-efficacy, according to Bandura (1997), refers to "beliefs in one's capabilities to organize and execute the courses of action required to produce given attainments." Learners' beliefs in their capabilities can be better predictors of performance than their real ability (Bandura, 1997; Schunk, 1991). Given its significance in human endeavors, scholars like Pajares and Urdan (2006) believe that it is impossible to examine some aspects of human functions such as learning, motivation, and academic achievements without examining the role of self-efficacy in the learners.

There have been a number of studies probing into the effects of self-efficacy on the second/foreign language learning in general and the effects on specific skills, such as writing, reading and listening as well as strategy use in particular. Hsieh and Schallert (2008) in their study demonstrated that self-efficacy was the strongest predictor of achievement among South Korean students who are studying English as a foreign language. Similar studies in Turkey (Tilfarlioğlu and Ciftci, 2011) revealed that there was a positive relationship between academic success as defined by grades and learners' self-efficacy beliefs. Mills, Pajares and Herron (2006), after surveying 95 college students who were learning French as a foreign language in the USA found that there was a significant positive relationship between the learners' reading self-efficacy beliefs and their reading proficiency. After reviewing several research studies examining the writing self-efficacy beliefs of young adolescents, Klassen (2002) discovered that self-efficacy was important in predicting students' writing behaviour. In their study of the elements that influence the development of writing skills, Chan and Abdullah (2004) found self-efficacy was one of the factors that could shape a writer's ability to write effectively. Rahimi and Abedini (2009) examined the relationship between self-efficacy and listening proficiency in Iranian context. The results of the study showed that the two were positively correlated.

Moreover, quite a few results from the survey studies suggested that the use of strategies is significantly related to self-efficacy beliefs. Magogwe and Oliver (2007) did a longitudinal study on 480 Botswana students who were learning English as a second language. They found that there was a significant relationship between the learners' strategy use and their self-efficacy beliefs. Su and Duo's study (2012) of 200 Taiwanese students, found that learning strategies are significantly associated with self-efficacy beliefs. Wong (2005) interviewed six Malaysian participants to examine their language learning strategies and self-efficacy beliefs. The study revealed that high-self-efficacy learners used more language learning strategies. In a similar vein, Wang and Li (2010) discovered that Chinese students' reading self-efficacy was positively correlated to their reading strategies namely metacognitive, social/affective and cognitive strategies. Readers with higher self-efficacy used more reading strategies than readers who had low self-efficacy.

In reviewing the literature, it seems that while many studies have been conducted on self-efficacy in relation to second and foreign-language learning in general, and writing, reading and listening in particular, research on self-efficacy with regard to speaking ability in foreign language learning is still lacking. Even fewer studies have been conducted to investigate the ways to enhance EFL students' speaking self-efficacy. The present study probes into the effects of college students' attending English Bar on their speaking self-efficacy. 
The questions examined were:

1) Are there any differences in self-efficacy between the students who often visit the Bar and their peers who seldom or never go to the Bar?

2) If the two groups of students differ in speaking self-efficacy, what contribute to the differences?

3) In what ways does the English Bar help the students in their spoken English?

\section{The Study}

To facilitate students' oral English practice after class, a national key university in south China decided to set up an English Practice Center in October, 2006. The center is composed of three functional zones, including the English Bar, the Mini-theater and the Interactive Center. The English Bar is cozily designed to bear the resemblance of a coffee bar where patrons sit in groups of three to four people and talk in English. The Mini Theatre is a place for many kinds of English performance, contests and movie viewing. The Interaction Space is chiefly for such activities as debates and lectures in English. The Center is non-profit and managed by a team of 12 students and a teacher is appointed by the university as the advisor. The students have free access to the FLPC, but formal applications must be made one week in advance for the use of the Mini-theater and the Interactive Center so that the activities are scheduled accordingly. The English Bar is open three times a week from 19:30 to 21:30 on Tuesday, Friday and Saturday evenings. Once in the Bar, the "patrons" are expected to speak English only. To control the use of English, one of the three bartenders would kindly remind the "offender" of the expectations or politely request them to leave. Besides the accommodating bartenders who volunteer in the Bar on shifts, a native English speaker (one of the three foreign teachers who are teaching English at the university) is assigned to visit the Bar to talk with the "patrons" as part of their work load. The non-alcoholic drinks, such as cola, Sprite, juice, as well as hot drinks such as coffee and tea, are served at the purchasing price.

Since its establishment, the FLPC has carried out a wide range of activities, including parties, lectures, movie shows, contests and other forms of activities. Several surveys have been conducted by the university to evaluate the effects of the FLPC on students' English learning. Among other findings, the English Bar has constantly been listed the most beneficial among the three zones. Given its popularity, it remains unclear yet why the Bar receives so much credit. This paper examines the ways in which the English Bar helps the students improve their oral competence and the relationship between Bar attendance and students' oral English self-efficacy so as to better serve the students in a culture like China where for many talking in English only occurs in classrooms.

\subsection{Sampling}

To understand the effects of English Bar participation on the attendees' self-efficacy and spoken English proficiency, the authors of the study administered a questionnaire to a total of 100 students. The participants were randomly sampled from all majors and grades in a key university in south China. The venues used to administer the questionnaire were school canteen, library and the English Bar. The students were divided into two categories: regular visitors who have visited the Bar at least once a week and control group who seldom or never visited the Bar in the semester when the survey was conducted. Before doing the questionnaire, they were asked to report their English achievement scores in the latest English examinations: excellent, 90 and above in a 100 scale; good, 75-89; average, 60-74; poor, below 60. The score served as the indicator of the students' English proficiency level. The students were also asked to mark their spoken English proficiency as compared to their peers (the advanced, the intermediate and the beginners).

\subsection{Questionnaire and In-Depth Interview}

An 18-item survey questionnaire adapted from Hairuzila Idrus et al. (2011) was administered to the sample of students to assess their self-efficacy perceptions. Since the questionnaire was in English, the author first tried it on four students majoring in translation who would later distribute the questionnaire. Thus the points in the items liable to misunderstandings were clarified and marked out so that they are able to explain to the students who in case had difficulty understanding the items.

The respondents indicated their degree of agreement or disagreement to each statement on a 5-point Likert scale that ranges from strongly disagree (1) to strongly agree (5). The 18 items were grouped into three categories, based on Hairuzila Idrus and colleagues' categorization (2011). The first category contained 12 items primarily dealing with students' perceived ability to speak in English. It was thus named Aptitude. The second one contained four items that address students' perceptions of activities that required them to speak in English. It was labelled Attitude and measured students' posture towards activities such as oral presentation and in-class discussions. The third category contained two items that measured traits such as students' desire to be fluent speakers of English. This category was named Aspiration. Pearson correlations were calculated in order to 
determine the relationship between the three categories of self-efficacy perceptions.

Table 1. Correlations between attitude, aptitude and aspiration

\begin{tabular}{|c|c|c|c|}
\hline & Aptitude & Attitude & Aspiration \\
\hline Aptitude & & $.81^{* *}$ & $.38^{* *}$ \\
\hline Attitude & & & $.48 * *$ \\
\hline Aspiration & & & \\
\hline
\end{tabular}

Note: $* *$ Correlation is significant at the 0.01 level (2-tailed)

As was shown in Table 1, there were positive and significant relationships between Attitude, Aptitude and Aspiration $(r=0.38$ to $r=0.81, p<0.01)$. The results indicate that the three constructs are interrelated. Level of self-efficacy in one construct is related to level of self-efficacy in the other two. Cronbach's alpha was used to measure the reliability coefficient of the entire scale. The three categories were all found to be reliable: the first category (Aptitude) had an alpha level of .92; the second one (Attitude), .83; the last one (Aspiration), .79. The overall alpha level for all three categories was .91. As such, the scale and each of the three categories are considered highly reliable.

Besides a questionnaire survey, the author also conducted in-depth interviews with the students and teachers who often visited the English Bar. Six students randomly chosen were interviewed. The author also interviewed three native English teachers who were assigned to attend to the Bar at least once a week. The interview with the students included three questions, ranging from the reasons they visit the Bar, the benefits they get from attending the Bar and their opinions on the management of the Bar. The questions for the teachers were mainly concerned with their ideas about the benefits of visiting the Bar and the ways they can help the students improve their oral English.

\section{Results}

The data were processed with SPSS 17.0. Independent sample T-test was done to calculate the differences in the mean scores of the two groups. The first test was to find the general differences between the two groups in the three categories.

Table 2. Mean scores and standard deviations of self-efficacy beliefs

\begin{tabular}{lllll}
\hline & Group & Mean & SD & Sig. \\
\hline Self-efficacy & A & 3.96 & .53 & $.000^{*}$ \\
& B & 3.10 & .66 & $.000^{*}$ \\
\hline
\end{tabular}

Note: Group A is the students who often visited the Bar; Group B is the students who seldom or never visited the Bar. The higher the score, the higher the self-efficacy level.

*significant at the 0.05 level (2-tailed).

In Table 2, the 18 items of the questionnaire were taken as one single construct. The statistical calculation reveals that the students who visited the English Bar have significantly higher self-efficacy level than their peers who seldom or never visited it.

Table 3. Mean scores and standard deviations of the three group construct

\begin{tabular}{lllll}
\hline Group Construct & Group & Mean & SD & Sig. \\
\hline Aptitude & A & 3.89 & .62 & $.000^{*}$ \\
& $\mathrm{~B}$ & 2.94 & .65 & $.000^{*}$ \\
Attitude & $\mathrm{A}$ & 4.02 & .58 & $.000^{*}$ \\
& $\mathrm{~B}$ & 3.19 & .80 & $.000^{*}$ \\
Aspiration & $\mathrm{A}$ & 4.21 & .73 & .113 \\
& $\mathrm{~B}$ & 3.91 & 1.10 & .114 \\
\hline
\end{tabular}

*significant at the 0.05 level (2-tailed). 
The 18 items of the self-efficacy questionnaire were then divided into three individual constructs, namely Aptitude, Attitude and Aspiration as was shown in Table 3. The students who often visited the Bar have significantly higher self-efficacy level in Aptitude than their peers who seldom or never visited it. In terms of Attitude, the two groups also differ dramatically and the difference reaches a statistically significant level. However, little difference was found in Aspiration between the two groups. Aspiration in this context means the strong desire to become someone who has a good command of English and can communicate with people effectively in English. Both groups got high scores in Aspiration indicates that they want to be fluent speakers of English for various reasons.

Table 4. Mean scores and standard deviations of the items that make up aptitude construct

\begin{tabular}{lllll}
\hline Item & Group & Mean & SD & Sig. \\
\hline 1. I think my oral English has improved a lot & A & 3.84 & .88 & $.000^{*}$ \\
since I started to visit the English Bar. & B & 2.46 & 1.03 & \\
2. I do a good job in class discussion in English. & A & 3.86 & .88 & $.000^{*}$ \\
& B & 2.80 & .69 & \\
3. I am now less nervous when I am talking to & A & 3.80 & .85 & $.000^{*}$ \\
people in English. & B & 3.40 & .96 & \\
4. I actively answer my English teachers' & A & 3.74 & .96 & $.000^{*}$ \\
questions in class. & B & 2.44 & .90 & \\
5. I feel confident about my ability to express & A & 3.90 & .99 & $.000^{*}$ \\
my ideas in English. & B & 2.60 & .90 & \\
6. I can motivate myself to speak in English. & A & 4.08 & .85 & $.000^{*}$ \\
& B & 3.10 & 1.11 & \\
7. I can communicate in English with my native & A & 4.06 & .79 & $.000^{*}$ \\
Chinese teachers of English. & B & 3.34 & 1.02 & \\
8. I can manage to make myself understood by & A & 3.98 & .89 & $.000^{*}$ \\
foreigners who speak English. & B & 3.38 & .90 & \\
9. I can learn and use new English words in my & A & 3.64 & .94 & $.000^{*}$ \\
conversation easily. & B & 2.94 & 1.05 & \\
10. I am able to keep speaking in English even & A & 3.88 & 1.00 & $.000^{*}$ \\
when my friends tease me. & B & 2.78 & .97 & \\
11. When I decide to say something in English, & A & 4.18 & .80 & $.000^{*}$ \\
I go ahead and do it. & B & 3.14 & .96 & \\
12. It is not difficult for me to concentrate while & A & 3.80 & .92 & $.000^{*}$ \\
speaking in English with others. & B & 2.90 & 1.14 & \\
\hline
\end{tabular}

*significant at 0.05 level (2-tailed).

Figures in Table 4 show that the two groups of students differ in the 12 individual items that make up Aptitude. The biggest difference is found in the students' responses to the fourth item. The students who often went to the English Bar to practice their spoken English were more active in answering the instructors' questions in the English language class than the control group. This is significant because answering teachers' questions in class can serve as a test on a formal occasion where the students check the skills they have learned in the English Bar. The second greatest contrast found between the two groups is in the mean scores of item one. Since the students in the contrast group seldom or never visited the Bar, they did not see any connection between visiting English Bar and their spoken English proficiency. Item five is closely linked to item four. The students who often visited the Bar reported more self-confidence than their peers in using English to express their ideas. With the increased confidence, they communicate more often with the teachers in classes and benefit more than their less active classmates.

The highest three scores the students who often went to the English Bar got are found in item eleven (4.18), six (4.08) and seven (4.06). The highest score in item 11 "When I decide to say something in English, I go ahead and do it." indicates that these students are very resolute in implanting the speaking act. It appears that the students who went to the English Bar to practice spoken English and joined in a conversation with one or more partners. 
They were less likely to hesitate but to respond quickly to other speakers. These students also scored high in item six "I can motivate myself to speak in English." To go to the English Bar regularly requires sustained effort especially on Friday and Saturday evenings when other students are having parties, shopping or playing computer games. Only those students with strong motivation are able to stay committed.

Table 5. Mean scores and standard deviations of the items that constitute attitude construct

\begin{tabular}{lllll}
\hline Item & Group & Mean & SD & Sig. \\
\hline 13. I am now less nervous when I am talking & $\mathrm{A}$ & 4.12 & .74 & $.000^{*}$ \\
to people in English. & $\mathrm{B}$ & 2.98 & 1.23 & \\
14. I do not find oral presentations in English & $\mathrm{A}$ & 3.98 & .79 & $.000^{*}$ \\
hard to do. & $\mathrm{B}$ & 3.18 & 1.15 & \\
15. I enjoy speaking in English with native & $\mathrm{A}$ & 4.12 & .91 & $.000^{*}$ \\
English speakers. & $\mathrm{B}$ & 3.72 & .92 & \\
$\begin{array}{l}\text { 16. Doing oral presentations in class is } \\
\text { enjoyable. }\end{array}$ & $\mathrm{A}$ & 3.88 & .79 & $.000^{*}$ \\
\hline
\end{tabular}

*significant at 0.05 level (2-tailed).

Table 5 shows that the two groups of students differ greatly in the four items that make up the category of Attitude. Those who often went to the Bar to practice their oral English skill reported that they enjoyed group discussion and oral presentation in class much more than their peers who seldom or never visited the Bar. It's interesting to note that although the two groups of students differed somewhat in their attitudes towards speaking to English native speakers, many students who seldom or never visited the Bar also enjoyed talking to native English speakers. As was mentioned before, in many places in China, college students don't have the chance to speak English to native speakers. Once they have the chance, they don't want to miss it. Talking to native speakers of English is fun for many because they can test their spoken English skills and at the same time they learn more about native English speakers' cultures.

Besides a questionnaire, the author also conducted in-depth interviews to students and native speakers of English who regularly visited the English Bar. Six randomly chosen students were interviewed. The interviews were conducted right after the Bar closed in the evenings in the last two weeks before the semester came to an end. Each interview lasted about half an hour. The recordings in MP3 were then converted into text by the author.

The three questions were:

1) What draw you to the English Bar?

2) In what ways does speaking English in the Bar help you improve your spoken English?

3) Where do you think the English Bar should improve to cater to your need?

Based on their self-reported speaking proficiency level, three interviewees were selected from the six, as they represented three types of speakers: advanced, intermediate and beginners.

Salina (pseudonym), a junior majoring in financial engineering, an English speaker of advanced level.

"I visit the English Bar on Friday or Saturday evening to force myself to speak English. I am afraid I may forget how to speak English. The English Bar is a place to make new friends and at the same time talking to people in English helps keep what I have now at least. I enjoy talking to the foreign teachers because they speak authentic English. I also like to share my experience in learning English with other students. One thing I think the Bar should improve is, let me see, eh... that the bartenders should propose a theme or themes every time for the people to talk about instead of letting the people talk anything they like. Another thing I'd like to propose is that if the Bar offers rooms for speakers of different levels, i.e. the advanced, intermediate and the beginners, it would be better.

Tom (pseudonym), a sophomore majoring in administration management, an English speaker of intermediate level.

"I come to the English Bar once a week, sometimes twice a week depending on my schedule. I want to study abroad for my master degree after I finish my study at this university, but I am worried about my English, especially my oral English. That's why I'm here. I learn from upper-classmates not only speaking skills but also 
ways to learn English. Another thing I got from my experience is that I'm now less nervous when I talk to my English teachers and foreigners. Last weekend I visited Hong Kong. I met an American on the subway and we talked in English for a few minutes. He told me that my English was good. Maybe he was being polite, but I felt good. One suggestion for the administrators is that the Bar should be open also in the afternoon and on the weekend."

Debby (pseudonym), a freshman majoring in journalism, started to speak English after she came to the university four months ago.

"My English wasn't good because I seldom spoke English in high school. When I started to visit(ed) the Bar four months ago, I felt very nervous, especially when I talked to foreigners. But the teachers, my partners and the Bar tenders were very kind and patient. With their encouragement and help, I learn quickly. And in the Bar, I can talk anything I like and I can choose a conversation partner as I like. This is different from an English class where I'm forced to speak. That's too normal (formal) and I'm afraid to make mistakes and to be corrected by the teacher in public. And I find the English I learn in the Bar is (too) useful than the things I learn in the classroom. Suggestions? Ok, every time I went to the Bar, there was only one foreigner who was surrounded by students. If I am late, I can hardly squeeze in. So I hope to see more native speakers there. Thank you. "

From the interviews, it's clear that in spite of the disparities in speaking proficiency levels, the students generally held a positive view towards the role of the Bar as a venue for students to practice and improve their oral English. This is consistent with the findings of the questionnaire survey. Students enjoyed the setting of the Bar which provided them with a non-threatening, informal environment where they were free to express themselves in English. Though all speakers benefited from interacting with their peers and native speakers of English, it was those students whose English is at the intermediate and lower levels that benefited most from the exposure to the all-English environment. The fact that they acquired not only practical skills in speaking English but also strategies to learn English from their peers and native speakers greatly strengthened their motivation to speak English on other occasions inside and outside the college campus. Tom and Debby's experiences are examples of social learning through interacting with upper-class students who serve as knowledgeable others. The presence of native speakers at the Bar contributed much to learner motivation, too. At the same time, this study also found that changes could be made in terms of management of the Bar to better cater to the students' needs.

As was mentioned before, at least one native English teacher was assigned to attend the Bar as part of their prescribed workload. The author also interviewed the three native speakers, two British, one American, via emails to get their views. The questions were:

1) Do you think the Bar is an appropriate place for the students to practice their spoken English skills? Why?

2) How do you motivate "the patrons" to speak English in the Bar?

The following are the texts converted from the emails.

Benjamin (pseudonym), a middle-aged Englishman, who has been teaching at the university for one semester when he received the interview.

"I think the English bar is a good place for the students to practice for the following reasons. It provides a safe environment where the students can practice both with the native English speaking teachers and each other. They go there knowing they will be expected to speak at least a little English. The students are free to participate as much or as little as they choose. They can sit and chat informally, and also take part in the organized activities provided by the student volunteers. Personally, I ask a lot of questions, or encourage the students to ask me questions, in English. The bar organizers could encourage the patrons by making a leaflet or something similar letting them know that everyone is expected to use English, and remind them that it is an informal place where they can feel free to speak as much or as little as they are comfortable doing."

Simon (pseudonym), a middle-aged Englishman who has been teaching at the university for one semester when he received the interview.

"The English Bar is a good place for students to practice their everyday practical English speaking skills because they can sit together in small, cozy groups, whether they are classmates or strangers. It's also a great place for like-minded people to meet and discuss their daily life. It's a good place to sit and drink a hot or cold beverage and discuss the day/week, relax and unwind in a laid-back environment with some soothing background music. They can share new vocabulary, phrases and unfamiliar idioms, learning from one another. I usually play board games such as Scrabble which is a vocabulary game. The students find it stimulating, competitive and exciting as well as educational and a great way to introduce new words and meanings and ways in which the words may be used in sentences. I feel that this style of learning is good for them because whilst 
they are distracted with a game, then they tend to relax and speak more without much hesitation."

Lisa (pseudonym), a middle-aged American woman who has been teaching at the university for one semester when she was interviewed.

"I think the English bar is a good venue for English language learners to practice their speaking and listening skills. The English bar is a non-intimidating and comfortable place for learners to engage in everyday conversations with fellow students and peers. It allows open conversation between peers of all levels. This open and diverse atmosphere creates a natural support system between learners. In this environment peers of all levels can assist each other in creating more intelligible spoken language. A method of building motivation would be to delegate a small group of language learners to lead in creating language activities and ask the patrons of the bar to participate in the activities. The activities should be lighthearted and simple but must be focused on building language skills. Making the most of student leaders creates an atmosphere of equality over authority and is generally less intimidating for the learners involved."

The three native speakers who were interviewed held positive views on the effects of the Bar on students' motivation to speak in English and its potential to enhance students' skill to interact with native and non-native speakers of English. They all agreed that the physical setting of the Bar provided an inviting and comfortable environment for the students to chat in English.

When given the freedom to choose casual and familiar conversation topics as well as partners who were friendly and helpful, the students feel that they have complete control over the learning process. As a result, their learning autonomy is strengthened. Besides, the students were also attracted by the native speakers who encouraged students to talk by asking them questions and involving them in games and other language learning related activities. And it also appears that the students who are shy and nervous in an English classroom turned out to be active speakers in the English Bar.

\section{Discussion}

The findings of the present study indicate that the students who often visit the Bar and those who seldom or never visit the Bar differ dramatically in their self-reported self-efficacy levels. Since self-efficacy can be reinforced or undermined by the outcomes of personal endeavors and by input from the environment (Schunk \& Pajares, 2009), attending the English Bar offers all things necessary to boost college students' speaking self-efficacy. Firstly, the setting of the Bar makes the students feel comfortable and relaxed, where they are free to choose the conversation partners as well as the topics. The experience of going to the Bar and the freedom the students enjoy may reduce their anxiety and stress to a minimum. Secondly, the students who do not speak English well are encouraged by the foreign teachers and their fellow students. Such encouragement serves as positive social persuasion that potentially strengthens students' speaking self-efficacy. Thirdly, by observing "similar others" who speak English well in the Bar, those students who are shy and nervous for lack of confidence or skills raise their self-efficacy by believing that they can one day become fluent speakers of the language. Finally, when the students realize they are making progress in using English to express their ideas, they are likely to motivate themselves to exert more effort in this regard.

The English Bar as part of a bigger project to boost college students' spoken English was welcomed by "the patrons" of all grades and majors on campus. The students, whether they have visited the Bar and in whatever frequency, have the desire to be good speakers of English. This could be explained by the fact that with China's ever-expending economy and involvement in globalization, college graduates with good communication skills in English have a better chance to land a job in the increasingly competitive talent market.

These findings have some pedagogical implications. The initiative to establish an FLPC has benefited many students who are eager to learn to communicate in English. And the success of the FLPC shows that such an all-English environment on campus is feasible with institutional support in funding and management. It's superior to traditional English Corners in that it has a fixed venue and schedule, with drinks served, friendly and accommodating bartenders speaking English only and most important of all, the presence of native speakers of English to attract students who would otherwise have no access to such face-to-face communications.

The fact that the students reported that they behaved quite differently in the Bar compared to in the classroom should inspire the teachers to improve classroom instruction. Sometimes students are unwilling to talk and get involved in class activities because the class may seem too formal and students have less freedom to choose the topics for discussion, to decide on the forms of activities, and have less control over the course of their learning. Thus it is the teachers' job to enliven the classroom atmosphere by making it less formal, selecting topics relevant to the students' experiences and interests, and constantly encouraging students whenever they make any 
progress however minor it is.

Though the English Bar is a venue for students to speak in English after class and its effect on motivating students to speak in English is salient, the suggestions the students have put forward to make it better serve them indicate that there are several changes yet to be made. For one thing, students differ greatly in their English proficiency levels, and they go to the Bar with different skills and learning expectations. For those students who are just beginning to speak English, they look forward to talking to more proficient speakers or native speakers in order to learn more; however, more proficient English speakers may not always be willing to be their "teachers". Another issue is in regard to conversation topics. Some students, as well as one native speaker in the interviews, suggest that every time the Bar is in session, the bartenders bring forth a topic or a few topics for the students to select and discuss. However, not all students like this idea, especially those who are still poor at listening and speaking. As mentioned above, they come to the Bar for the freedom to talk about whatever they have an interest in and not to be restrained by the prescribed topics. These are the few problems revealed in this study that the author believes pose a challenge to the administrators of the Bar.

This study has its limitations. First, the sampling is small, thus less representative of the overall student population. Secondly, because of the differences found in speaking self-efficacy beliefs within student groups, more needs to be done on how students with different English proficiency levels differ in such beliefs and on what extent such beliefs help students sustain their effort on a long term basis. Despite these limitations, this study sheds some light on the effect of a self-managed English speaking practice center on students' speaking self-efficacy development.

\section{References}

Bandura, A. (1997). Self-efficacy: The exercise of control. New York: W. H. Freeman and Company.

Cai, J. G. (2011). On college English curriculum and teaching objectives. Foreign Language Teaching and Research, 11(4), 609-617.

Chan, S. H., \& Abdullah, A. N. (2004). Exploring affect in ESL writing behaviour. Retrieved March 24, 2006, from http://www.melta.org.my/ET/2004/2004-1.pdf

Cortazzi, M., \& Jin, L. (1996). Cultures of learning: Language classrooms in China. In Coleman, H. (Ed.), Society and the Language Classroom (pp. 169-206). Cambridge University Press, Cambridge.

Deckert, G. (1993). Perspectives on plagiarism from ESL student in Hong Kong. Journal of Second Language Writing, 2(2), 131-148.

Flowerdew, J., \& Miller, L. (1995). On the notion of culture in L2 Lectures. TESOL Quarterly, 29(2), 345-373.

Gao, X. (2006). A tale of Blue Rain Cafe: A study on the online narrative construction about a community of English learners on the Chinese mainland. System, 35, 259-270. http://dx.doi.org/10.1016/j.system.2006.12.004

Gao, X. (2006b). Interpreting Chinese students' motives in a weekly English discussion group: A case study. Asian Journal of English Language Teaching, 16, 129-143.

Hsieh, P. P., \& Kang, H. S. (2010). Attribution and self-efficacy and their interrelationship in the Korean EFL context. Language Learning, 60(3), 606-627. http://dx.doi.org/10.1111/j.1467-9922.2010.00570.x

$\mathrm{Hu}, \mathrm{G}$. W. (2002). Recent important developments in secondary English-language teaching in the People's Republic of China. Language, Culture and Curriculum, 15(1), 30-49.

$\mathrm{Hu}$, G. W. (2003). English language teaching in China: Regional differences and contributing factors. Multilingual and Multicultural Development, 24(4), 290-314.

$\mathrm{Hu}, \mathrm{G}$. W. (2005). Contextual influences on instructional practices: A Chinese case for an ecological approach to ELT. TESOL Quarterly, 39(4), 635-660. http://dx.doi.org/10.2307/3588525

Idrus, H., Salleh, R., \& Abdullah, M. R. T. L. (2011). Oral communication ability in English: An essential skill for engineering graduates. Asian Pacific Journal of Educators and Education, 26(1), 107-123.

Jiang, X., \& Smith, R. (2008). Chinese learners' strategy use in historical perspective: A cross-generational interview-based study. System, 37, 286-299. http://dx.doi.org/10.1016/j.system.2008.11.005

Klassen, R. (2002). Writing in early adolescence: A review of the role of self-efficacy beliefs. Educational Psychology Review, 14, 173-203.

Li, Y. (2004). Investigating 'English Corners' in tertiary campuses: Communication modes and self-identity 
construction. In Gao, Y. (Ed.), Social Psychology of English Learning by Chinese College Students: Motivation and Learner's Self-identities (pp. 202-226). Foreign Language Teaching and Research Press, Beijing, China.

Liu, M. X. (2011). A new approach to teaching college students listening and speaking. Jinan Higher Education Research, 11(2), 46-48.

Magogwe, J. M., \& Oliver, R. (2007). The relationship between language learning strategies, proficiency, age and self-efficacy beliefs: A study of language learners in Botswana. System, 35, 338-352. http://dx.doi.org/10.1016/j.system.2007.01.003

Mills, N., Pajares, F., \& Herron, C. (2006). A reevaluation of the role of anxiety: Self-efficacy, anxiety, and their relation to reading and listening proficiency. Foreign Language Annals, 39(2), 276-294. http://dx.doi.org/10.1111/j.1944-9720.2006.tb02266.x

Pajares, F., \& Urdan, T. (2006). Foreword. In F. Pajares, \& T. Urdan (Eds.), Self-efficacy beliefs of adolescents (pp. 9-12). Greenwich, CT: Information Age Publishing.

Rahimi, A., \& Abedini, A. (2009). The interface between EFL learners' self-efficacy concerning listening comprehension and listening proficiency. Novitas Royal, 3(1), 14-28.

Raoofi, S., Tan, B. H., \& Chen, S. H. (2012). Self-efficacy in second/foreign language learning Contexts. English Language Teaching, 5(11), 60-73. http://dx.doi.org/10.5539/elt.v5n11p60

Schunk, D. H. (1991). Self-efficacy and academic motivation. Educational Psychologist, 26, 207-231.

Schunk, D. H., \& Pajares, F. (2009). Self-efficacy theory. Handbook of motivation at school (pp. 35-53).

Su, M. H., \& Duo, P. C. (2012). EFL learners' language learning strategy use and perceived self-efficacy. European Journal of Social Sciences, 27(3), 335-345.

Tilfarlioğlu, F. T., \& Ciftci, F. S. (2011). Supporting self-efficacy and learner autonomy in relation to academic success in EFL classrooms (A Case Study). Theory and Practice in Language Studies, 1(10), 1284-1294. http://dx.doi.org/10.4304/tpls.1.10.1284-1294

Wang, C., \& Li, Y. (2010). An empirical study of reading self-efficacy and the use of reading strategies in the Chinese EFL context. The Asian EFL Journal Quarterly, 12(2), 144-162.

Wong, S. L. (2005). Language learning strategies and language self-efficacy. Investigating the relationship in Malaysia. RELC Journal, 36(3), 245-269.

\section{Appendix}

\section{A. 英语口语能力调查问卷}

同学们:

为了更好地促进英语口语教学, 我们特设计了该问卷。请你仔细阅读每一个题, 并根据你自己的实际情 况选择相应的数字。你的意见对我们的研究很重要, 谢谢。

做问卷之前, 请完成下列选择:

你的英语口语水平: A. 很流利 B. 流利 C. 一般 D. 比较差
你的英语成绩:
A. 优秀（90分以上）
B. 很好 (80-89)
C. 中等 (70-79)
D. 比较差（70分以下）

\section{你经常到“英语吧”练习口语吗？ A. 经常 B. 很少或从未去过}

\section{(1=不同意; $5=$ 完全同意, 请打 $\sqrt{ }$ )}

\begin{tabular}{|c|c|}
\hline $\begin{array}{l}\text { 1. I think my oral English has improved a lot } \\
\text { since I started to visit the English Bar. }\end{array}$ & $1-2-3-4-5$ \\
\hline 2. I do a good job in class discussion in English. & $1 \quad 2 \quad 3 \quad 3 \quad 4 \quad 5$ \\
\hline $\begin{array}{l}\text { 3. I am now less nervous when I am talking to } \\
\text { people in English. }\end{array}$ & $1{ }^{2}{ }^{2} 3 \quad 4 \quad 5$ \\
\hline $\begin{array}{l}\text { 4. I actively answer my English teacher's } \\
\text { questions in class. }\end{array}$ & $1-2-3-4-5$ \\
\hline $\begin{array}{l}\text { 5. I feel confident about my ability to express my } \\
\text { ideas in English. }\end{array}$ & $1 \_2 \_3 \_4 \_5$ \\
\hline
\end{tabular}




\begin{tabular}{|c|c|}
\hline 6. I can motivate myself to speak in English. & $1 \_2 \quad 3 \quad 4 \quad 5$ \\
\hline $\begin{array}{l}\text { 7. I can communicate in English with my native } \\
\text { Chinese teachers of English. }\end{array}$ & $1{ }^{2}-3 \quad 3 \quad 4 \quad 5$ \\
\hline $\begin{array}{l}\text { 8. I can manage to make myself understood by } \\
\text { foreigners who speak English. }\end{array}$ & $1 \ldots 2 \_3 \quad 4 \quad 5$ \\
\hline $\begin{array}{l}\text { 9. I can learn and use new English words in my } \\
\text { conversation easily. }\end{array}$ & $1 \_2-3-4 \quad 5$ \\
\hline $\begin{array}{l}\text { 10. I am able to keep speaking in English even } \\
\text { when my friends tease me. }\end{array}$ & $1 \_2 \_3 \quad 4 \quad 5$ \\
\hline $\begin{array}{l}\text { 11. When I decide to say something in English, I } \\
\text { go ahead and do it. }\end{array}$ & $1 \_2 \_3 \_4-5$ \\
\hline $\begin{array}{l}\text { 12. It is not difficult for me to concentrate while } \\
\text { speaking in English with others. }\end{array}$ & $1{ }^{2}-3 \quad 3 \quad 4 \quad 5$ \\
\hline $\begin{array}{l}\text { 13. I enjoy having group discussions in class in } \\
\text { English. }\end{array}$ & $1 \_2 \_3 \_4 \quad 5$ \\
\hline $\begin{array}{l}\text { 14. I do not find oral presentations in English hard } \\
\text { to do. }\end{array}$ & $1{ }^{2}-3-4-5$ \\
\hline $\begin{array}{l}\text { 15. I enjoy speaking in English with native } \\
\text { English speakers. }\end{array}$ & $1 \_2-3 \_4-5$ \\
\hline 16. Doing oral presentations in class is enjoyable. & $1 \_2 \_3 \_4 \quad 5$ \\
\hline $\begin{array}{l}\text { 17. Speaking fluently in English is one of my } \\
\text { main goals in life. }\end{array}$ & $1 \_2 \_3 \quad 4 \quad 5$ \\
\hline $\begin{array}{l}\text { 18. I want to speak good English just like other } \\
\text { students who are good speakers. }\end{array}$ & $1 \_2 \_3 \_4 \_5$ \\
\hline
\end{tabular}

B. Interview Questions:

For the students:

1) What draws you to the English Bar?

2) In what way does speaking English in the Bar help you improve your spoken English?

3) Where do you think the English Bar should improve to cater to your need?

For the teachers:

1) Do you think the Bar is an appropriate place for the students to practice their spoken English skills? Why?

2) How do you motivate "the patrons" to speak English in the Bar?

\section{Copyrights}

Copyright for this article is retained by the author(s), with first publication rights granted to the journal.

This is an open-access article distributed under the terms and conditions of the Creative Commons Attribution license (http://creativecommons.org/licenses/by/3.0/). 